\title{
Long-Term Effects of Expiration of Derivatives on Indian Spot Volatility
}

\author{
Sunita Narang ${ }^{1}$ and Madhu Vij ${ }^{2}$ \\ ${ }^{1}$ Acharya Narendra Dev College, University of Delhi, Delhi 110019, India \\ ${ }^{2}$ Faculty of Management, University of Delhi, Delhi 110007, India \\ Correspondence should be addressed to Sunita Narang; narang.sunita20@gmail.com
}

Received 16 June 2013; Accepted 16 July 2013

Academic Editors: M. T. Leung, S. Managi, and K. P. Upadhyaya

Copyright (c) 2013 S. Narang and M. Vij. This is an open access article distributed under the Creative Commons Attribution License, which permits unrestricted use, distribution, and reproduction in any medium, provided the original work is properly cited.

\begin{abstract}
This paper examines the impact of expiration of derivatives on spot volatility of Indian capital market. The review of the literature shows that the previous Indian studies have covered a period of only 4-6 years after the introduction of derivative trading in India in 2000. They are unanimous about volume effect but not about return and volatility effect. This paper uses regression techniques and one symmetric and three asymmetric GARCH models, namely, TGARCH, EGARCH, and PGARCH, to evaluate the impact. It uses daily data on popular index S\&P CNX Nifty of National Stock Exchange of India, during a period of more than a decade from June 12, 2000 to January 10, 2012. Findings of the study show that spot returns, volume, and volatility are high on expiration day and they build up further on the day after expiry which shows that the Indian market is weakly efficient. The expiration effect is mainly due to concentration of volumes in near-month contracts and absence of physical settlement.
\end{abstract}

\section{Introduction}

Derivatives were introduced on two major exchanges of India, namely, National Stock exchange (NSE) and Bombay Stock Exchange (BSE) in 2000. During this time Indian government took many decisions to bring major structural changes in the market. NSE acted as a catalytic agent in reforming the micro structure, market practices, and trading volumes of the Indian securities market. It is dominating the derivative segment with more than $99 \%$ of the market share in 2011-12. The exchanges manage their respective cash and derivative segments which have been well integrated with uniform trade practices and trade timings. Screen-based trading allows the arbitrageurs to use computer programs for identifying arbitrage conditions and ensures quick execution of orders. Index and stock-based derivatives are traded in monthly series, the expiration date for each series being the last Thursday of the expiry month, that is, Indian market experiences the quadruple witching day. At any point of time, three monthly series are traded side by side and are cash settled on the expiration or an early exercise.

As derivative contracts call for cash settlement on the expiration day, the trading and manipulation activities of speculators and unwinding of cash positions by arbitrageurs in the cash markets sometimes cause distortion to price, volume, and volatility near the expiration day. If many arbitrageurs liquidate at the same time and in the same direction, price and volatility effects are possible. Speculators can also make deliberate attempts to manipulate prices. The severity of these effects partially depends on the stock market procedures for accommodating order imbalances. Considering the fact that a large number of derivative transactions take place on this day, the magnitude of these potential side effects can be large. Also, since index arbitrage is typically executed with expensive computer technology, the potential benefits are reaped by only a small number of institutional investors, but the side effects are suffered by all market participants.

During 2001-08, highly liquid index futures and options provided a simple and efficient arbitrage opportunity to traders. Futures and options contracts were cash settled so there was no direct pressure due to delivery demands on the cash market on expiration days. As opposed to these facilitators of a smooth arbitrage, short sales in the cash market were banned during this period by the Indian market regulator SEBI which may have constrained the arbitrage transactions requiring a short position in the cash market. 
After 2008, the ban on shortsales was lifted. Since then there is significant increase in use of computer programs for doing arbitrage, known as algorithmic trading. It is yet to be seen if these changes have altered the impact of expiration day on the volatility of Indian spot market.

\section{The Literature Review}

Many previous studies have pointed towards significant expiration effects in terms of high volume and volatility. The studies [1-8] found significant volume effects on account of expiration days. Apart from higher volume, the studies [9-12] also found evidence of a reversal of the index. The studies $[6,13-15]$ found increased volatility in individual stock returns. [16] for TSE 300 Index and [17] for Spanish Exchange found that price reversals, higher trading volume, and higher volatility are associated with expiration days. On the other hand, $[18,19]$ found no significant expiration-day effect on cash-market volatility. This indicates that world over researchers are unanimous about the volume effect of expiration day. The impact on returns and volatility, however, is not clear. Some studies show return reversal whereas others do not. Similarly, some researchers report high volatility and others find it insignificant.

In case of India, most of the studies are reporting significant expiration effect during a period of 4-6 years after introduction of derivatives in $2000[1,7,8]$. Indian researchers also agree on volume effects while, the results regarding price effects and volatility effects are mixed $[1,2,7,8]$. Since researchers in India and abroad are not unanimous about volatility effect, it needs to be further examined whether and to what extent the expiration effects add to higher than normal volatility and whether this volatility has a detrimental effect. Our study proposes to use a longer period to get comprehensive results on all the three variables, namely, return, volume, and volatility, for this emerging market by using econometric models.

\section{Data}

NSE established itself as the market leader in the futures and options segment since the inception of derivative trading in 2000. Its benchmark index, S\&P CNX Nifty, is a well diversified index consisting of 50 liquid stocks; hence, the study considers Nifty as a proxy for the Indian stock market and uses its time series data to see the impact of derivative expiration on stock market volatility. The impact of expiration-day is evaluated during post derivative period; hence, daily closing prices of approximately 13 years, from June 12, 2000 to January 10, 2012, have been collected from the website of NSE. The total period has approximately 2393 days out of which 127 days are the expiration days and 126 days are non expiration days.

To separate the impact of US market (proxy for world) from that of domestic market on volatility, the data of S\&P 500 index is used as an additional independent variable. S\&P 500 is widely regarded as the best single gauge of the US equities market; this world-renowned index includes a representative sample of 500 leading companies in leading industries of the US economy. The correlation coefficient of Nifty and S\&P 500 shows that they are highly correlated and the US market significantly affects the Indian market. We have also collected the volume data of Nifty spot index to evaluate the impact of derivative expiration on it.

\section{Econometric Technique}

For analysis of impact of derivative expiration we calculate the return series by taking log of first difference of the daily closing prices of S\&P Nifty and S\&P 500 US index. Trading volume is also calculated using logarithms. Current financial time series exhibit the phenomena of volatility clusters and if it is not captured then the empirical findings are not reliable. Hence, we have used GARCH(1,1) model, proposed by [20], to capture this effect.

GARCH models display some limitations in capturing stylized characteristics of the data like heavy tails, asymmetric (leverage) effect, volatility clustering. The most important feature is asymmetric effect which was discovered by [21], and confirmed by the findings of [22-24], among others. This effect results when predictable volatility increases more due to unexpected drop in price (bad news) than unexpected increase in price (good news) of same magnitude. According to $[21,25]$, this is due to leverage effect. A drop in price increases financial leverage, which makes the stock riskier and increases its volatility. Many researchers treat leverage effect same as asymmetric volatility. We are capturing the asymmetric effect using three models, namely, EGARCH model by [23], TGARCH model by [26], and PGARCH model by [27, 28].

Finally, there is a variety of statistics to evaluate and compare forecast errors in the volatility forecasting literature. The most popular measures used in the literature include mean error (ME), root mean square error (RMSE), mean absolute percentage error (MAPE), and mean absolute error (MAE). We have chosen measures of RMSE, MAE, and MAPE for comparing the performance of various GARCH models we have used.

\section{Method}

5.1. Impact of Derivative Expiration on Spot Volume. We analyse the impact of derivative expiration on spot volume using regression technique with a dummy variable for expiration day. This variable takes the value of 1 on the last Thursday of the month when derivative contracts expire in India and 0 otherwise. Apart from this we also employ dummy variable for next day and see its impact on the spot volume. Next, we take the Thursday prior to expiry day as the non expiration day and employ dummy variable for assessing its impact on spot volume.

5.2. Impact of Derivative Expiration on Spot Return and Volatility. Second, we employ GARCH and its asymmetric counterparts to examine the impact of expiration day, next day, and non expiration day on spot return and spot volatility using dummy variables. We also use multiplicative volume 
dummies to find the impact of expiration day, next day, and non expiration day volumes on spot return and volatility.

\section{Empirical Results}

6.1. Descriptive Statistics. To observe the preliminary difference in returns of expiry day, its next day and non expiry day, we start with descriptive statistics of these days (see Table 1).

The results in Table 1 show that the mean and unconditional variance of returns is highest during next days and lowest during non expiration days. The skewness statistics indicates higher probability of getting higher returns on next day compared to expiry day. Its positive value during non expiration days suggests high probability of getting lower returns. The kurtosis and JB statistics indicate that next day returns are more normal than expiry day returns while returns are highly non normal during non expiry days.

6.2. Impact of Derivative Expiration on Spot Volume. To reveal any effects of expiration day and its next day on the trading volume of the Nifty spot index, regression model was evaluated with the following results:

$$
\begin{aligned}
\operatorname{Ln}\left(\operatorname{vol}_{t}\right)= & 2.1374 * c+0.8829 * \operatorname{Ln}\left(\operatorname{vol}_{t-1}\right) \\
& +0.1319 * \text { Expday, } \\
\operatorname{Ln}\left(\operatorname{vol}_{t}\right)= & 2.0648 * c+0.8877 * \operatorname{Ln}\left(\operatorname{vol}_{t-1}\right) \\
& +0.1479 * \text { Nextday }
\end{aligned}
$$

where $\operatorname{Ln}\left(\mathrm{vol}_{t}\right)$ is the logarithm of trading volume on day $t$ and $\operatorname{Ln}\left(\operatorname{vol}_{t-1}\right)$ is the volume on previous day. Expday and Nextday are the dummies for expiration day and its next day, respectively.

The results show that the coefficients of the dummies for both expiration day and its next day are positive and significant (1\%) and the magnitude is higher on the next day. This shows that expiration period increases the spot volume and that there is no reversal in volume during this period. We could not find the presence of autocorrelation and heteroscedasticity in the volume data hence OLS is an appropriate method.

Next, we see the impact of non expiration day on spot volume as follows:

$$
\begin{aligned}
\operatorname{Ln}\left(\operatorname{vol}_{t}\right)= & 2.1216 * c+0.8842 * \operatorname{Ln}\left(\operatorname{vol}_{t-1}\right) \\
& -0.0225 * \text { NExpday. }
\end{aligned}
$$

The results in the previous equation show that the coefficient of non expiry day is negative and insignificant. Consequently, it can be concluded that derivative expiration has a significant positive effect on the volume of Nifty.

\subsection{Impact of Derivative Expiration on Spot Return and} Volatility. To evaluate the impact of expiry day and its volume on spot return and volatility we augment the GARCH return and volatility equations with the dummies of expiry day, its multiplicative dummy with volume; next day, its
TABle 1: Descriptive statistics of expiration and nonexpiration periods.

\begin{tabular}{lccc}
\hline & Expiry day & Next day & Nonexpiry day \\
\hline Mean & 0.0033 & 0.0034 & 0.0010 \\
Std. Dev. & 0.0132 & 0.0166 & 0.0094 \\
Skewness & -0.2523 & -0.4475 & 0.4988 \\
Kurtosis & 4.5947 & 3.9711 & 7.9259 \\
Jarque Bera & $14.11^{* * *}$ & $8.72^{* *}$ & $255.75^{* * *}$ \\
No. of Obs. & 127 & 126 & 126 \\
\hline
\end{tabular}

${ }^{* *}$ indicates significance at $5 \%$.

${ }^{* * *}$ indicates that values are significant at $1 \%$.

multiplicative dummy with volume; and non expiry day and its multiplicative dummy with volume. The results are shown in Tables 2, 3, and 4 .

The results in Table 2 show that the impact of expiry day its volume is highly significant (1\%) and positive on both spot return and volatility under Ged distribution.

The results in Table 3 show highly significant (1\%) and positive impact of next day and its volume on spot returns and volatility under Ged distribution.

By comparing Tables 2 and 3 we can see that the impact of next day on return and volatility is higher than the impact of expiry day, suggesting continuation of an upward pressure. This indicates that no price or volatility reversal is taking place. This implies that expiration period is profitable for Indian market participants. Apart from this, we also note that the volumes are also higher on next day compared to expiry day. These volumes are partially responsible for high returns and volatility during expiration period. The results in Table 4 suggests that impact of non expiration day is positive and insignificant on returns and negative and insignificant on volatility. This implies that Indian market experiences significant expiration effects in terms of high returns, volumes, and volatility.

\section{Conclusions}

The analysis of post derivative period for expiration effect indicates that return, volume, and volatility are high on expiry day, and all these variables further increase on next day, indicating continuation of upward pressure. This indicates negative price, volume, and volatility reversal. The volume on expiry and next days is partially responsible for high returns and volatility on these days.

High volumes on these days may be attributed to various reasons: unwinding of large position; discretionary liquidity trading; and more active trading by informed traders during this period [29].

Although, Indian government has tried to implement physical settlement but it is yet to take off; hence, the cash settlement feature of derivatives may be contributing to high returns during these days. Increase in returns on both expiry and next day could also be due to flow of new information into the market which implies that Indian market is weakly efficient [30]. According to [6], if the underlying market is deep and if suppliers of liquidity are quick to respond to 
TABLE 2: Impact of expiry day and its volume on spot return and volatility.

\begin{tabular}{|c|c|c|c|c|}
\hline & $\operatorname{Garch}(1,1)$ & TGarch $(1,1)$ & $\operatorname{EGarch}(1,1)$ & PGarch $(1,1)$ \\
\hline Nifty $(-1)$ & $0.0404^{* * *}$ & $0.0527^{* * *}$ & $0.0318^{* *}$ & $0.0426^{* * *}$ \\
\hline S\&P 500(-1) & $0.2103^{* * *}$ & $0.2111^{* * *}$ & $0.2163^{* * *}$ & $0.2186^{* * *}$ \\
\hline Expday & $0.0032^{* * *}$ & $0.0030^{* * *}$ & $0.0033^{* * *}$ & $0.0038^{* * *}$ \\
\hline Expday $*$ Lnvol & $0.0002^{* * *}$ & $0.0002^{* * *}$ & $0.0002^{* * *}$ & $0.0002^{* * *}$ \\
\hline Alpha & $0.1499^{* * *}$ & $0.0600^{* * *}$ & $0.1398^{* * *}$ & $0.1264^{* * *}$ \\
\hline Gamma & - & $0.1859^{* * *}$ & $-0.0429^{* * *}$ & $0.5389^{* * *}$ \\
\hline Beta & $0.8125^{* * *}$ & $0.7918^{* * *}$ & $0.9375^{* * *}$ & $0.8317^{* * *}$ \\
\hline Expday & $4.34 E-005$ & $5.41 E-05^{*}$ & $0.3971^{* * *}$ & $0.0023^{* *}$ \\
\hline Expday $*$ Lnvol & $2.36 E-006$ & $2.82 E-06^{*}$ & $0.0226^{* * *}$ & $0.0001^{* *}$ \\
\hline $\log L$ & 6947.2 & 6954.69 & 6938.1 & 6957.73 \\
\hline RMSE & 0.021030 & 0.021006 & 0.020998 & 0.020976 \\
\hline MAE & 0.010981 & 0.010959 & 0.010945 & 0.010934 \\
\hline MAPE & 177.39 & 170.14 & 166.13 & 156.25 \\
\hline
\end{tabular}

${ }^{*}$ indicates significance at $10 \%$.

${ }^{* *}$ indicates significance at $5 \%$.

${ }^{* * *}$ indicates that values are significant at $1 \%$.

TABLE 3: Impact of next day and its volume on spot return and volatility.

\begin{tabular}{|c|c|c|c|c|}
\hline & $\operatorname{Garch}(1,1)$ & TGarch $(1,1)$ & EGarch $(1,1)$ & PGarch(1,1) \\
\hline Nifty(-1) & $0.0358^{* *}$ & $0.0437^{* * *}$ & 0.0208 & $0.0264^{*}$ \\
\hline S\&P 500(-1) & $0.2119^{* * *}$ & $0.2136^{* * *}$ & $0.2144^{* * *}$ & $0.2147^{* * *}$ \\
\hline Nextday & $0.0039^{* * *}$ & $0.0043^{* * *}$ & $0.0046^{* * *}$ & $0.0047^{* * *}$ \\
\hline Nextday $*$ Lnvol & $0.0002^{* * *}$ & $0.0002^{* * *}$ & $0.0002^{* * *}$ & $0.0003^{* * *}$ \\
\hline Alpha & $0.1526^{* * *}$ & $0.0671^{* *}$ & $0.1378^{* * *}$ & $0.1269^{* * *}$ \\
\hline Gamma & - & $0.1813^{* * *}$ & $-0.0331^{* *}$ & $0.5367^{* * *}$ \\
\hline Beta & $0.8119^{* * *}$ & $0.7974^{* * *}$ & $0.9479^{* * *}$ & $0.8411^{* * *}$ \\
\hline Nextday & $5.3 E-05^{*}$ & $6.13 E-05^{* *}$ & $0.4269^{* * *}$ & $0.0029^{* * *}$ \\
\hline Nextday $*$ Lnvol & $2.96 E-06^{*}$ & $3.37 E-06^{* *}$ & $0.0235^{* * *}$ & $0.0002^{* * *}$ \\
\hline $\log L$ & 6952.92 & 6958.54 & 6940.28 & 6962.28 \\
\hline RMSE & 0.021008 & 0.020954 & 0.020959 & 0.020954 \\
\hline MAE & 0.010950 & 0.010914 & 0.010916 & 0.010914 \\
\hline MAPE & 171.34 & 146.57 & 148.39 & 146.25 \\
\hline
\end{tabular}

${ }^{*}$ indicates significance at $10 \%$.

${ }^{* *}$ indicates significance at $5 \%$.

${ }^{* * *}$ indicates that values are significant at $1 \%$.

TABLE 4: Impact of nonexpiry day and its volume on spot return and volatility.

\begin{tabular}{|c|c|c|c|c|}
\hline & $\operatorname{Garch}(1,1)$ & $\operatorname{TGarch}(1,1)$ & $\operatorname{EGarch}(1,1)$ & PGarch $(1,1)$ \\
\hline $\operatorname{Nifty}(-1)$ & $0.0358^{* *}$ & $0.0408^{* *}$ & 0.0226 & 0.0216 \\
\hline S\&P 500(-1) & $0.2164^{* * *}$ & $0.2194^{* * *}$ & $0.2285^{* * *}$ & $0.2297^{* * *}$ \\
\hline NExpday & 0.0005 & 0.0002 & 0.0002 & 0.0002 \\
\hline NExpday $*$ Lnvol & $4.85 E-005$ & $1.47 E-005$ & $9.77 E-006$ & $1.21 E-05$ \\
\hline Alpha & $0.1507^{* * *}$ & $0.0689^{* *}$ & $0.1229^{* * *}$ & $0.1192^{* * *}$ \\
\hline Gamma & - & $0.1766^{* * *}$ & -0.0188 & $0.4774^{* * *}$ \\
\hline Beta & $0.8152^{* * *}$ & $0.7987^{* * *}$ & $0.9557^{* * *}$ & $0.8554^{* * *}$ \\
\hline NExpday & $-1.65 E-005$ & $-2.37 E-005$ & 0.0505 & -0.0006 \\
\hline NExpday $*$ Lnvol & $-8.61 E-007$ & $-1.21 E-006$ & 0.0035 & $-3.39 E-05$ \\
\hline $\log L$ & 6966.97 & 6973.63 & 6592.78 & 6973.36 \\
\hline RMSE & 0.021012 & 0.020949 & 0.020964 & 0.020932 \\
\hline MAE & 0.010938 & 0.010918 & 0.010921 & 0.010917 \\
\hline MAPE & 173.16 & 149.18 & 150.27 & 148.35 \\
\hline
\end{tabular}

** indicates significance at $5 \%$.

$*^{* *}$ indicates that values are significant at $1 \%$. 
selling or buying pressure, the price effects of large arbitrage unwinding will be small. The results of our study indicate significant effect on price which means that the market mechanisms in India are not well designed to offset surprise imbalances and there is a need to further increase the depth of markets.

High volatility on both expiry and next day indicates that investors are undecided and prefer to roll over their position. It could also be due to manipulation activities. This temporary increase in volatility cannot destabilize the markets in long run. Further, our study shows that non expiry days contribute to insignificant return and volatility. Thus, we conclude that Indian market experiences significant expiration effect.

The study proves that Indian spot market experiences high volume and volatility during expiration of near-month derivative contracts. Large gaps exist in the range of derivative products that are traded actively. Most of the trading happens in near month contracts. On a typical trading day in the middle of the month, about 98 percent of the turnover comes from near-month contracts, while less than 0.5 percent comes from the far-month series. Of the individual stocks traded in the futures and options market, far-month contracts of only about 10 percent are traded. The concentration of volumes in the near-month series means that this is speculators' market. The manipulation by speculators is the main reason behind high volatility during and after expiry of these contracts. The impact of expiry day volume on return and volatility shows that positive and significant causality is running from volume to return and volatility which means that prices are speculative and traders take large spot positions to cover their risk resulting in high volatility during expiration period. This implies that volumes in near-month contracts should be regulated. Further, regulators should take necessary steps to curb volatility whenever volumes increase to a higher than normal level during expiration. This can also be achieved by popularising far-month contracts.

\section{References}

[1] B. S. Bodla and K. Jindal, "Equity derivatives in India: growth pattern and trading volume effects," ICFAI Journal of Derivatives Markets, vol. 5, pp. 62-82, 2008.

[2] S. S. Debasish, "Investigating expiration day effects in stock index futures in India," Journal of Economics and Behavioral Studies, vol. 1, pp. 9-19, 2010.

[3] A. G. Karolyi, "Stock market volatility around expiration days in Japan," Journal of Derivatives, vol. 4, no. 2, pp. 23-43, 1996.

[4] P. F. Pope and P. K. Yadav, "The impact of option expiration on underlying stocks: the UK evidence," Journal of Business Finance \& Accounting, vol. 19, pp. 329-344, 1992.

[5] C. Schlag, "Expiration-day effects of stock index derivatives in Germany," European Financial Management, vol. 2, pp. 69-95, 1996.

[6] H. R. Stoll and R. E. Whaley, "Expiration-day effects of the all ordinaries share price index futures: empirical evidence and alternative settlement procedures," Australian Journal of Management, vol. 22, no. 2, pp. 139-174, 1997.

[7] N. Tripathy, "Expiration and week effect: empirical evidence from the Indian derivative market," International Review of Business Research Papers, vol. 6, pp. 209-219, 2010.
[8] V. Vipul, "Futures and options expiration-day effects: the Indian evidence," The Journal of Futures Markets, vol. 25, no. 11, pp. 1045-1065, 2005.

[9] H. R. Stoll and R. E. Whaley, Expiration Day Effects of Index Options and Futures, Monograph Series in Finance and Economics, Monograph 1986-3, New York University, 1986.

[10] H. R. Stoll and R. E. Whaley, "Program trading and expirationday effects," Financial Analysts Journal, vol. 43, no. 2, pp. 16-18, 20-28, 1987.

[11] H. R. Stoll and R. E. Whaley, "Program trading and individual stock returns: ingredients of the triple-witching brew," The Journal of Business, vol. 63, no. 1, pp. S165-S192, 1990.

[12] H. R. Stoll and R. E. Whaley, "Expiration-day effects: what has changed?" Financial Analysts Journal, vol. 47, no. 1, pp. 58-72, 1991.

[13] Y.-F. Chow, H. H. M. Yung, and H. Zhang, "Expiration day effects: the case of Hong Kong," The Journal of Futures Markets, vol. 23, no. 1, pp. 67-86, 2003.

[14] D. Lien and L. Yang, "Availability and settlement of individual stock futures and options expiration-day effects: evidence from high-frequency data," The Quarterly Review of Economics and Finance, vol. 45, no. 4-5, pp. 730-747, 2005.

[15] H. M. Maniar, R. Bhatt, and D. M. Maniyar, “"Expiration hour effect of futures and options markets on stock market"a case study on NSE (National Stock Exchange of India)," International Review of Economics and Finance, vol. 18, no. 3, pp. 381-391, 2009.

[16] T. W. Chamberlain, C. S. Cheung, and C. C. Y. Kwan, "Expiration-day effects of index futures and options: some Canadian evidence," Financial Analysts Journal, vol. 45, no. 5, pp. 67-71, 1989.

[17] M. Illueca and J. A. LaFuente, "New evidence on expirationday effects using realized volatility: an intraday analysis for the Spanish stock exchange," The Journal of Futures Markets, vol. 26, no. 9, pp. 923-938, 2006.

[18] P. Corredor, P. Lechón, and R. Santamaría, "Option-expiration effects in small markets: the Spanish stock exchange," The Journal of Futures Markets, vol. 21, no. 10, pp. 905-928, 2001.

[19] D. Lien and L. I. Yang, "Options expiration effects and the role of individual share futures contracts," The Journal of Futures Markets, vol. 23, no. 11, pp. 1107-1118, 2003.

[20] T. Bollerslev, "Generalized autoregressive conditional heteroskedasticity," Journal of Econometrics, vol. 31, no. 3, pp. 307327, 1986.

[21] F. Black, "Studies in stock price volatility changes," in Proceedings of the Business Meeting of the Business and Economics Statistics Section, pp. 177-181, American Statistical Association, 1976.

[22] K. R. French, G. W. Schwert, and R. F. Stambaugh, "Expected stock returns and volatility," Journal of Financial Economics, vol. 19, no. 1, pp. 3-29, 1987.

[23] D. B. Nelson, "Conditional Heteroskedasticity in asset returns: a new approach," Econometrica, vol. 59, pp. 347-370, 1991.

[24] G. Schwert, "Stock volatility and the crash of "87"', Review of Financial Studies, vol. 3, pp. 77-102, 1990.

[25] A. A. Christie, "The stochastic behavior of common stock variances. Value, leverage and interest rate effects," Journal of Financial Economics, vol. 10, no. 4, pp. 407-432, 1982.

[26] L. R. Glosten, R. Jagannathan, and D. E. Runkle, "On the relation between the expected value and the volatility of the nominal excess return on stocks," Journal of Finance, vol. 48, no. 5, pp. 1779-1801, 1983. 
[27] S. Taylor, Modeling Financial Time Series, John Wiley \& Sons, New York, NY, USA, 1986.

[28] G. Schwert, "Why stock market volatility change over time?" Journal of Finance, vol. 44, pp. 1115-1153, 1989.

[29] A. R. Admati and P. Pfleiderer, "A theory of intraday patterns: volume and price variability," Review of Financial Studies, vol. 1, pp. 3-40, 1988.

[30] E. F. Fama, "Multi-period consumption-investment decisions," American Economic Review, vol. 60, pp. 163-174, 1970. 


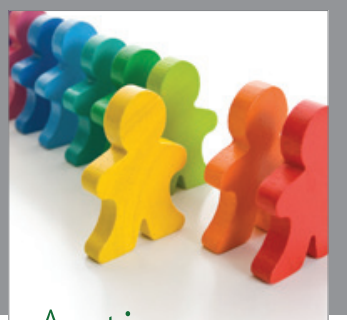

Autism

Research and Treatment
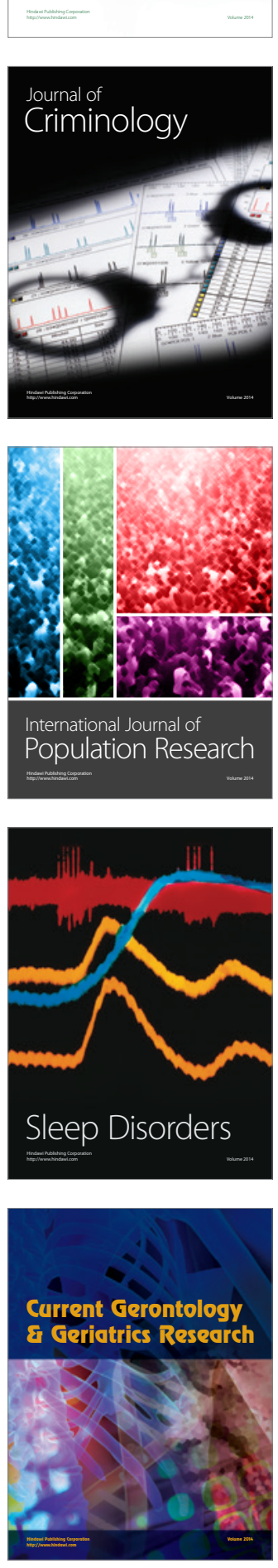
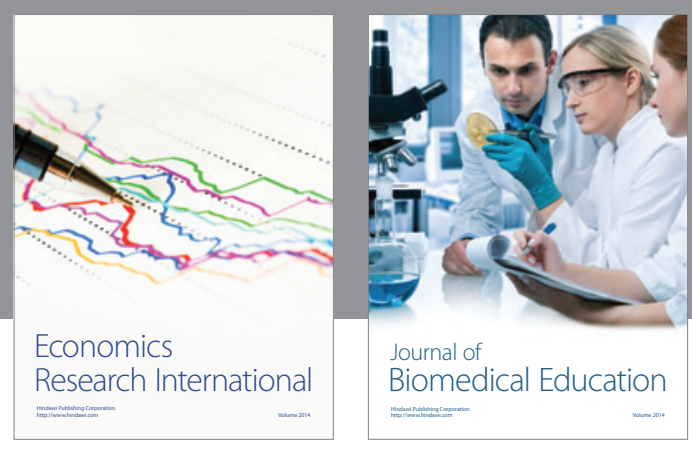

Journal of

Biomedical Education

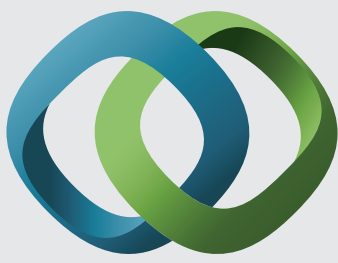

\section{Hindawi}

Submit your manuscripts at

http://www.hindawi.com
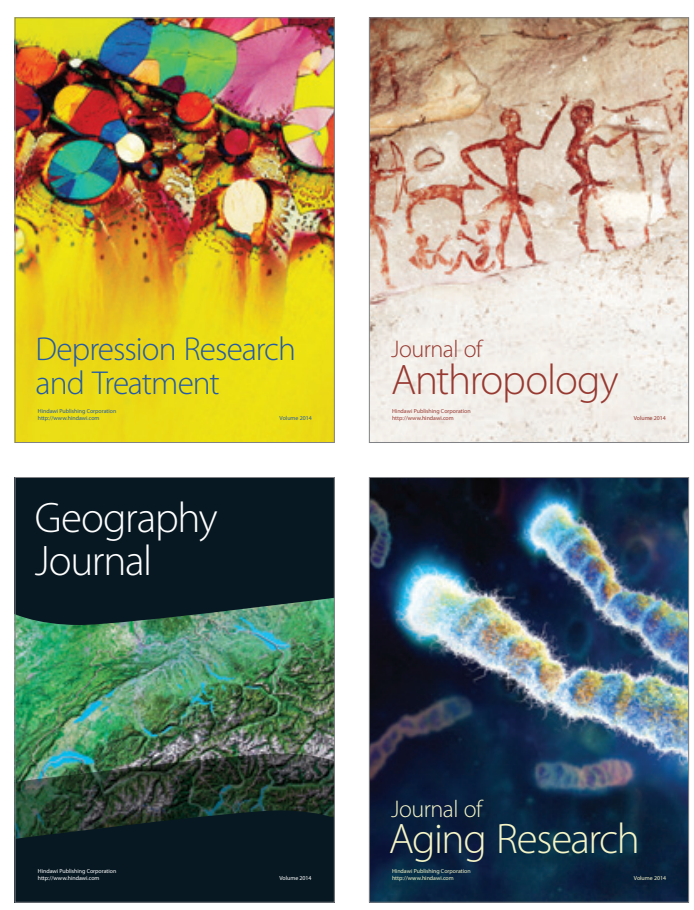

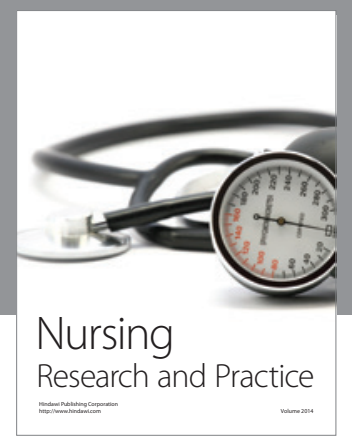

Nursing

Research and Practice

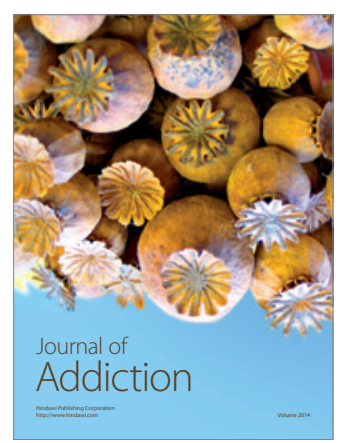

Child Development

Research

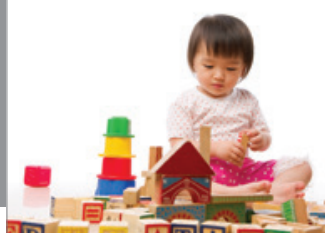

迥
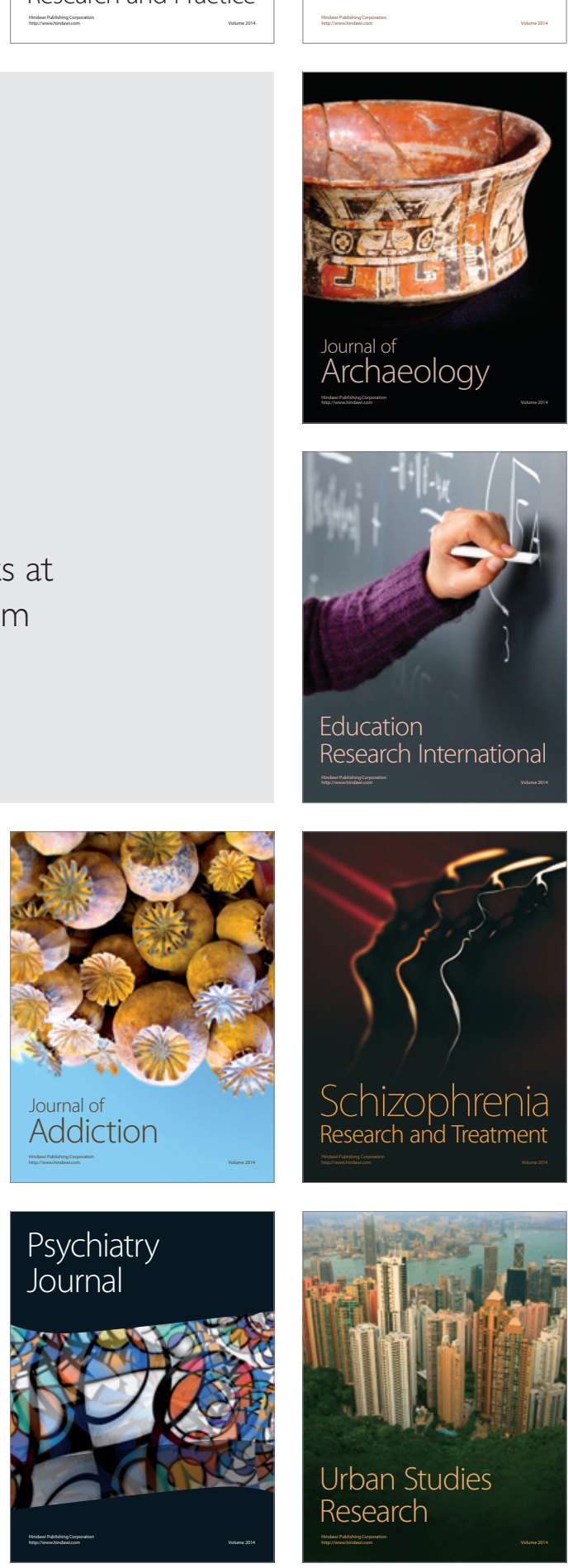